\title{
Where Do We Stand on Transport Infrastructure Deregulation and Public-Private Partnership?
}

\author{
Antonio Estache and Tomás Serebrisky ${ }^{1}$
}

\begin{abstract}
The evolution of transport public-private partnerships (PPPs) in developing and developed countries since the early 1990s seems to be following a similar path: private initiatives work for a while but after a shock to the sector takes place the public sector returns as regulator, owner or financier; after a while the public sector runs into problems and eventually finds a hybrid solution to ensure the survival of the sector. This paper reviews the effectiveness of transport infrastructure deregulation from three angles: efficiency, fiscal and users' viewpoint. The paper emphasizes the difficulties and strong political commitments required to make the reforms sustainable and argues that governments willing to make corrections to the reform path are faced with the need to address recurrent and emerging issues in transport systems: tariff structure, quality (timetable, safety, environment), access rules for captive shippers, the trend toward rebundling and decrease in intrasectoral competition, multimodalism and the stimulus through yardstick competition.
\end{abstract}

World Bank Policy Research Working Paper 3356, July 2004

The Policy Research Working Paper Series disseminates the findings of work in progress to encourage the exchange of ideas about development issues. An objective of the series is to get the findings out quickly, even if the presentations are less than fully polished. The papers carry the names of the authors and should be cited accordingly. The findings, interpretations, and conclusions expressed in this paper are entirely those of the authors. They do not necessarily represent the view of the World Bank, its Executive Directors, or the countries they represent. Policy Research Working Papers are available online at http:/lecon.worldbank.org.

\footnotetext{
${ }^{1}$ Both authors are with the World Bank, the first one is also affiliated with the ECARES at the Universite Libre de Bruxelles. Contact information: aestache@worldbank.org, tserebrisky@worldbank.org. We are grateful to J.A. Gomez-Ibañez, C. von Hirschausen, J.J. Laffont, R. Schlirf, G. Tracz, L. Trujillo, Paul Amos, Emile Quinet, John Dodgson, José Barbero, Chris Nash and John Preston for helpful discussions and comments on earlier versions. This paper was produced for a Round Table of the Joint OECD/ECMT Transport Research Centre.
} 


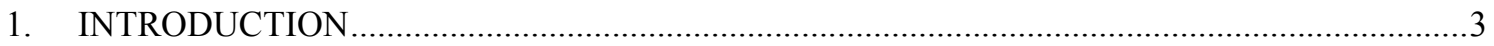

2. HOW BIG IS THE ROLE FOR THE PRIVATE SECTOR IN TRANSPORT

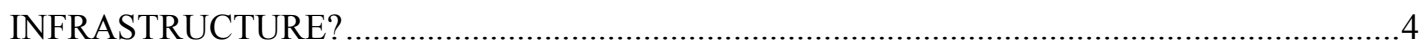

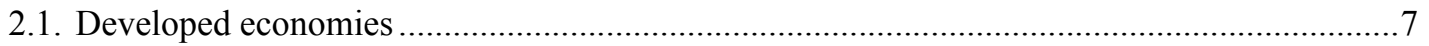

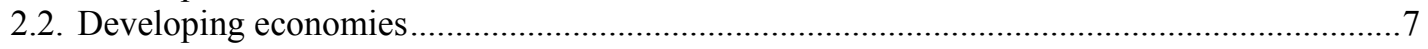

3. FORMS OF PRIVATE SECTOR PARTICIPATION IN TRANSPORT …...............................10

4. HAS TRANSPORT DE-REGULATION AND RESIDUAL REGULATION BEEN

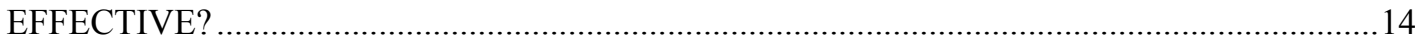

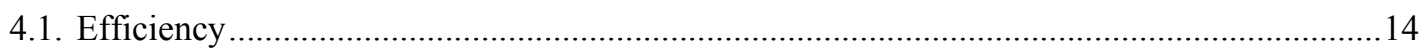

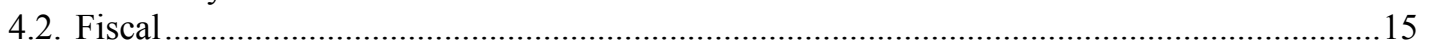

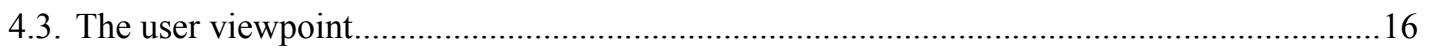

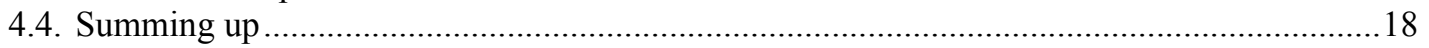

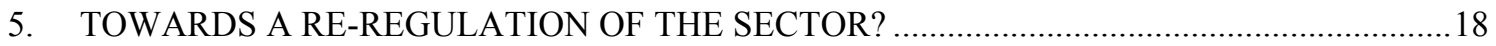

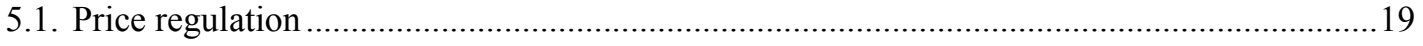

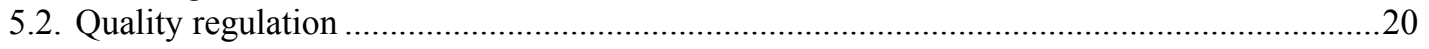

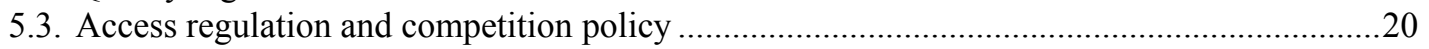

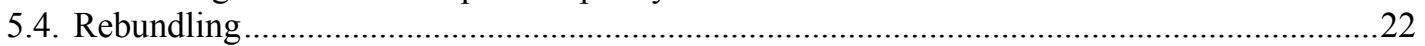

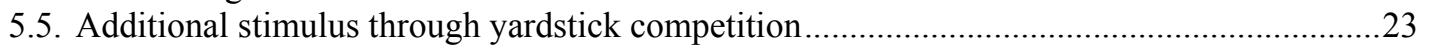

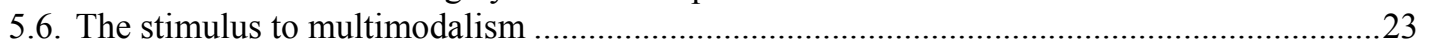

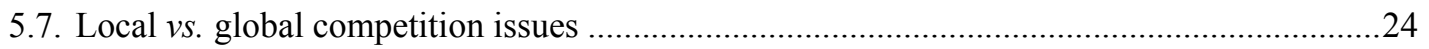

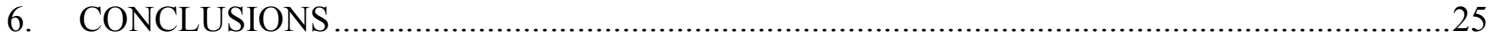

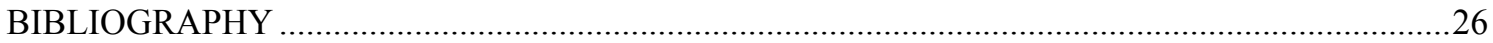




\section{INTRODUCTION}

The history of the transport sector shows that, whether the focus is on buses, railways, roads or even airports and ports, the tale of public-private partnerships and their regulation is one of recurring policy themes. This recurrence is what allows us to draw better lessons over time as experiences evolve - and supposedly allows their internalization in the next wave of policy reforms. The learning is slow because there are many dimensions to address including, sometimes, dimensions complex enough to make the deregulation and ownership issues more of a significant anecdote rather than the center of the debate. The history of the railways sector in the United Kingdom nicely motivates the associated policy, competition and regulation issues that arise in the context of the recurring cycles that characterize the evolving role of the state in transport. ${ }^{2}$

The first railway carrying passengers and freight in Great Britain, the Stockton \& Darlington Railway, was created in 1825 as a private company; it was much more willing to take the chance on a new vision than the public sector was. The state had no or little role and no costs. The network was developed through a piecemeal approach in which each line was being promoted by a small private company, relying on the equivalent of Build-Operate-Own (BOO) projects for the times. The system was thus efficient in that it was following demand but inefficient in that it did not reflect the potential economies of scale. Large, long-distance operators eventually took over the smaller lines, improving the economies of scale. Eventually, in 1923, almost all the railways in the country were grouped into four new big companies. The State started to worry about concerns for competition in the sector. As a result of a drop in demand, in the late 1940s, the sector became financially unviable and the state took over through a nationalization of all assets. Throughout the 1950s, the sector continued to be restructured with a view to shrink it, adjusting supply to demand to cut fiscal costs. The 1970s saw mixed modernization efforts managed by the public sector at increasing fiscal costs. The $1980 \mathrm{~s}$, as a result of yet another macroeconomic shock-- the 1979 oil price shock --saw a major deterioration in the demand for railway services and a further fiscal hit. By the 1990s steps were put in place to restructure (including deregulation and privatization) the railways to cut the fiscal burden. The circle seemed to have closed but not quite. By the end of the decade, unhappiness with the private model grew, to a large extent because of concerns for safety, while the trains were at the same time becoming fashionable again, to a large extent because of a growing concern about congestion and pollution. The government is thus now returning to the sector, as a very active regulator and possibly financier, and a new hybrid model seems to be emerging, starting what is likely to be a second turn on the enlarged "ownership circle".

The main purpose of this paper is to show that, to a large extent, the evolution of public-private partnerships (PPPs) in developed and developing countries since the early 1990s is very similar to the one observed for the British railways: private initiatives work for some things for a while, then some internal but often major shock external to the sector takes place and the public sector comes into the

2. A similar story is told for the evolution of public-private partnerships in the bus sector, with illustrations for Chile and Colombia in Estache and Gomez-Lobo (2004). 
picture first as a regulator, then as an owner or at least financier; after some time the public sector runs itself into problems and tries to get the private sector back and eventually hybrid solutions are found to ensure the survival of a sector for which the demand is strong, the economic impact brutal, but for which the financing structure needs to better account not only for the financial cost of the business but also for the major economic, social and political dimensions. ${ }^{3}$ After a decade of increased private sector participation, the cycle is now at the stage of its evolution at which governments need to define how hybrid they want their transport systems to be and the specific actual responsibility they want to assign to themselves.

To document this story and to show that we are at a point in history at which the cycle is likely to take us back to an increased role for the public sector in transport infrastructure, the paper is organized as follows. In section 2, we provide a sense of the absolute and relative importance of the private sector in transport infrastructure from a global and regional viewpoint. In section 3, we give a sense of the main types of contractual arrangements that have been adopted and the associated problems. In section 4, we review the evidence on the effect of deregulation and re-regulation on the relative efficiency of public and private provision of transport services. In section 5, we discuss the main new regulatory and competition issues emerging in the sector and their social consequences. Section 6 concludes.

\section{HOW BIG IS THE ROLE FOR THE PRIVATE SECTOR IN TRANSPORT INFRASTRUCTURE?}

The specific measurement of deregulation in transport infrastructure is not an easy task. Most of the information is anecdotal and, unlike what is happening in telecoms or energy for instance, the international associations for the sector do not keep track of the progress made following a standard typology of reforms. Because most of the information available is anecdotal, it can hardly be organized into a detailed useful typology. The big picture is however relatively straightforward and is best illustrated by the evolution of reforms in rail and ports.

Railways have now been or are being deregulated in many countries, although with very diverse degrees of commitment to competition in and for the market. In most of North, Central and South America, in the largest countries of Oceania, in some of the largest systems of Africa and in many of the largest countries of East Asia (with the noticeable exception of China), the private sector is now the key player with the public sector confined to a regulatory role varying from a simple role as contract supervisor to the coordinator of complex timetables, the monitor of service quality and the key actor in tariff revisions when these are needed. Europe is also on its way to deregulate its railways but following a very "European" model unmatched in other parts of the world. The main region who opted out so far is South Asia. Despite the trend illustrated in this paragraph, it should be pointed out that apart from the United States, the largest national railways systems in the world (Russia, China, India, Germany) still are largely public.

3. For an overview of the core issues in restructuring, privatization and regulation of the transport sector, see, for instance, Estache and de Rus (2000). 
Ports have also enjoyed strong reforms. Since the early 1990s, port deregulation has been widespread and the private sector is now one, if not the, key actor in most large countries of America, Africa, Oceania and even in the largest countries of Asian such as China and India. As in the case of railways, Europe lags the other regions in terms of deregulation and continues to have hybrid organizational structure in which the public sector continues to play a key role as provider, financier and regulator simultaneously. The overall picture of the sector can be summarized with some estimates made by Drewry (2002). In 1991, the public sector handled about $42 \%$ of container port throughput but by 2001 its share had dropped to about $27 \%$ with a strong concentration in South East Asia and Western \& Eastern Europe ${ }^{4}$.

One indicator that gives a sense of the outcome of these restructuring and deregulation efforts over the last eighteen years is the number of new transport infrastructure projects considered by the private sector as countries were liberalizing the sector. Public Works Financing roughly compiles this information. According to this source, between 1985 and 2003, 1137 new transport projects worth US\$ 684 billion were planned around the world. This implies an average project size of US\$600 million. The distribution of these projects by transport sub-sector shows that toll roads accounts for 50 percent while rail, airports and ports account for $22 \%, 16 \%$ and $12 \%$ of the total commitments respectively. Their distribution across regions shows that about $60 \%$ of these projects are committed to developing countries but 55\% of the amounts committed are for developed countries. Table 1 also shows that the average project size varies significantly across regions with the largest average projects in Europe and Asia. The average project size in developing countries is about half the size in developed countries.

While these commitments numbers give a useful sense of the upper limit of the private sector flows in the sector, they may somewhat be misleading. Indeed, only half of the new projects reported up to end of 2003 had effective financing -i.e. were under construction or operation. ${ }^{5}$ The evolution of these commitments is however interesting. It shows that since the 1997 Asia crisis, the number of commitments has dropped significantly but much more importantly in developing than in developed countries.

Overall, this implies that even though the deregulation of transport did generate enthusiasm during the early part of the 1990s, the Asia crisis and the overall instability of financial markets were enough to slow down and even overturn these commitments by the private sector. Many more reasons contribute to explain why effective disbursement lags behind. Some of them are country specific pace of privatization/liberalization process, institutional organization, rule of law- while others are influenced by global conditions - mainly crisis in financial markets. A more detailed look at the differences between developed and developing economies can provide useful insights.

\footnotetext{
${ }^{4}$ Certainly, the private sector dominates stevedoring (particularly container handling) activities, but when ownership of quays, shipping channels, breakwaters and navigation aids are considered, the public sector remains the key player almost everywhere.
}

5. $47 \%$ of projects and $51 \%$ of total funds. 
Table 1. Evolution of Total Planned Commitments to Transport Projects in the World

Investment commitment amounts, numbers of project commitments and average size of project commitments

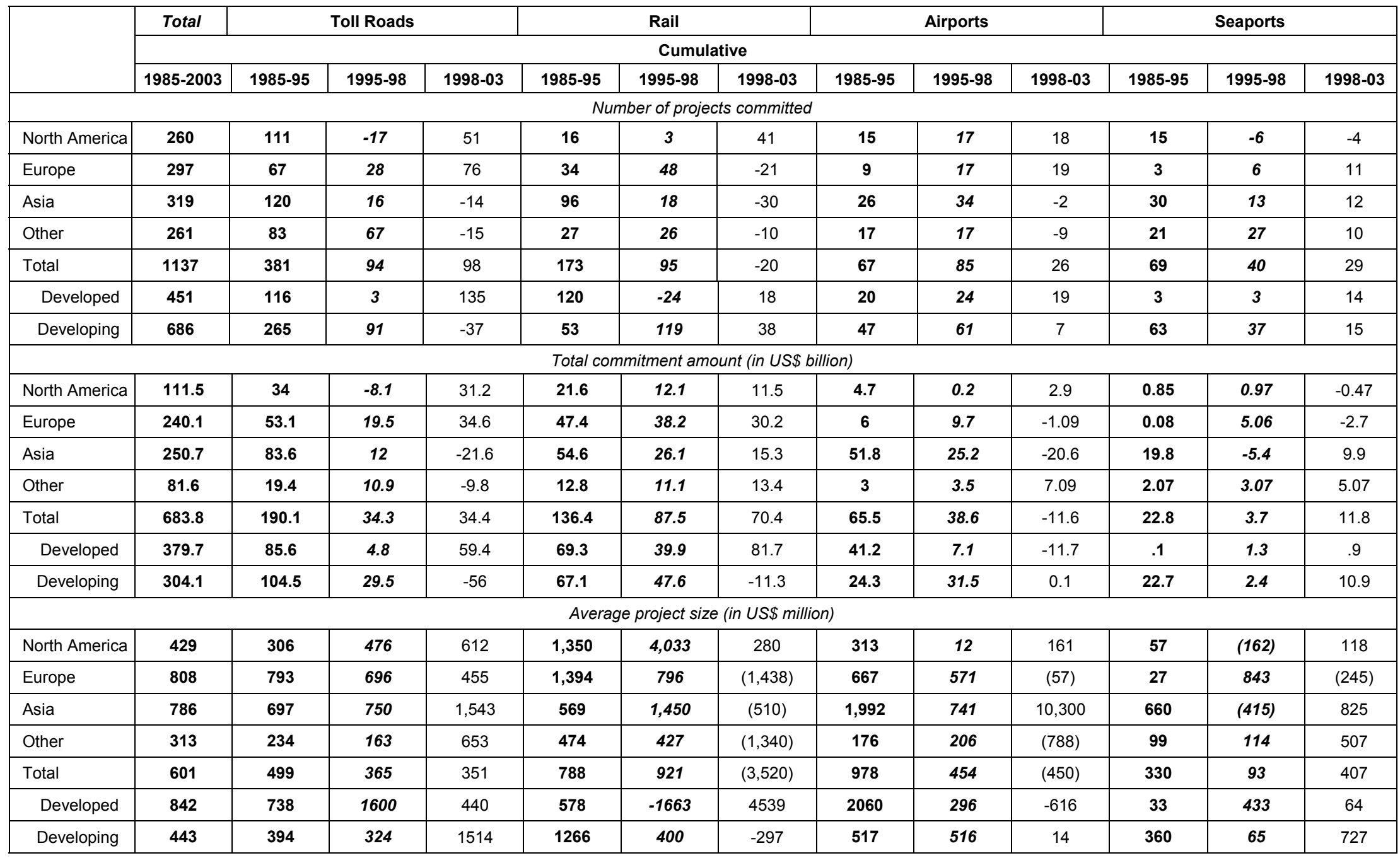

Source: Public Works (2003) and authors' calculations. 


\subsection{Developed economies}

Two-thirds of the private projects credited to developed countries accrue to 5 countries: US (122 projects), Spain (66), UK (64), Australia (46) and Canada (37). Adding Portugal (22), Germany (19), Ireland (16) and Greece (14) covers $90 \%$ of the projects during the period 1985-2003. In terms of commitments, the ranking is somewhat different. The UK enjoys $27 \%$ of the commitments, the US 17\%, Japan 8\%, Italy and Spain 7\%, Canada 6\% and Australia 5\%. The sectoral composition of the projects reveals nicely the subsectoral demand. Toll roads and rail projects attract the most attention reflecting the increased demand for passenger mobility in developed countries and in Europe due to the increased integration of the continent. Seaports do not seem to need new investments, consistent with the wide perception that there may be an excess capacity in the sector and that many of the ports continue to be maintained for political or strategic reasons. Airport projects are heavily concentrated in the United States, Australia and the UK where the size of the first two countries and the insular character of the third one ensure that the increased demand for passenger mobility is not monopolized by ground transportation.

The statistics also reflect the levels and commitments of the governments of the top three countries to private sector participation in the transport sector. The US has indeed a long tradition which for the last fifteen years or so has been actively followed by the UK and Australia. More recently, following the liberalization stimulus of the European Commission many countries in continental Europe are actively involving the private sector in the transport sector. In particular, Portugal, Greece and Spain have experienced a significant increase in the quantity of projects planned, often with the financing of the regional development funds of the EEC.

\subsection{Developing economies}

The commitments published by Public Works are known to be overestimates of the actual numbers but also to sometimes fail to account for new projects in some regions and sectors in developing countries. The World Bank has been publishing for some time now more refined estimates of these commitment figures trying to separate wishful-thinking by sponsors from serious commitments. This database covers actual deals -rather than planned projects as in the case of the Public Works database- on projects that have reached financial closure in water, electricity, natural gas, telecommunications and transport. It deals exclusively with projects in which the private company assumes operating risk during the operating period or assumes development and operating risk during the contract period. Investments and privatization revenues are recorded on a commitment basis in the year of financial closure. Actual disbursements are not tracked.

This effort results in a significant drop in the estimates to US\$135 billion between 1990 and 2001, implying that the total commitments to transport in the world were at most US\$515 billion rather than US\$684 billion. For developing countries, this implies an average project size of US\$204 millions, or less than $50 \%$ of the estimate provided in Table 1 . Considering that the world counts 155 countries defined as developing, the average commitment per country would be about US $\$ 80$ million dollars per year. ${ }^{6}$ The average project size implies that at least half of the countries do not benefit from any project. The privatization experience has in fact been even more concentrated than expected. Indeed, China, Brazil, Argentina, Mexico and Malaysia concentrated most of the investment during the period, although with strong fluctuations over time. Up to the Tequila Crisis, these

6. This kind of back-of-the-envelope estimation shows why the share of financing of transport infrastructure by the private sector is likely to be much lower than the $20 \%$ estimated by DFIF (2002) for the whole of the infrastructure sector. 
countries explained more than $80 \%$ of total investments, reducing their share to $50 \%$ in 1995 . In 1998 their share was again over $80 \%$ but after the Asian crisis it has been falling, reaching just over $30 \%$ in 2002. Globally, the developing countries transport sector only attracted about $18 \%$ of the total investment flows that accrued to the infrastructure sector. It lags significantly behind the telecommunications $(44 \%)$ and electricity $(28 \%)$ sectors.

Table 2. Estimates of Transport Infrastructure Projects

having reached financial closure in developing and transition economies (1990-2001)

\begin{tabular}{|c|c|c|c|c|c|c|c|}
\hline & Africa & $\begin{array}{c}\text { East } \\
\text { Asia }\end{array}$ & $\begin{array}{c}\text { Eastern } \\
\text { Europe }\end{array}$ & $\begin{array}{c}\text { Latin } \\
\text { America }\end{array}$ & $\begin{array}{c}\text { Middle } \\
\text { East }\end{array}$ & $\begin{array}{c}\text { South } \\
\text { Asia }\end{array}$ & Total \\
\hline AIRPORT & & & & & & & \\
\hline Number of transactions & 10 & 17 & 14 & 32 & 7 & 2 & 82 \\
\hline Value in millions of US\$ & 375 & 2,625 & 1,500 & 7,125 & 750 & 125 & 12,500 \\
\hline PORT & & & & & & & \\
\hline Number of transactions & 10 & 52 & 16 & 78 & 8 & 13 & 177 \\
\hline Value in millions of US\$ & 180 & 8,820 & 720 & 5,580 & 900 & 1,800 & 18,000 \\
\hline RAIL & & & & & & & \\
\hline Number of transactions & 9 & 11 & 7 & 48 & 1 & 0 & 76 \\
\hline Value in millions of US\$ & $\mathbf{2 8 8}$ & 10,080 & $\mathbf{2 8 8}$ & 17,856 & 288 & 0 & 28,800 \\
\hline ROAD & & & & & & & \\
\hline Number of transactions & 9 & 149 & 6 & 137 & 0 & 26 & 327 \\
\hline Value in millions of US\$ & 2,280 & 34,200 & 2,770 & 36,000 & 0 & 750 & 76,000 \\
\hline TOTAL & & & & & & & $\mathbf{4 1}$ \\
\hline Number of transactions & $\mathbf{3 8}$ & $\mathbf{2 2 9}$ & $\mathbf{4 3}$ & $\mathbf{2 9 5}$ & $\mathbf{1 6}$ & $\mathbf{6 6 2}$ \\
\hline Value in millions of US\$ & $\mathbf{3 , 1 2 3}$ & $\mathbf{5 5 , 7 2 5}$ & $\mathbf{5 , 2 7 8}$ & $\mathbf{6 6 , 5 6 1}$ & $\mathbf{1 , 9 3 8}$ & $\mathbf{2 , 6 7 5}$ & $\mathbf{1 3 5 , 3 0 0}$ \\
\hline
\end{tabular}

Source: World Bank, Infrastructure Vice-Presidency, PPI Database.

The sectoral distribution of projects (measured in US\$) is just as skewed toward road deals as it is in developed countries simply because the increase in demand for passenger mobility is also very high. The distribution of projects in the developing world also shows however the impact of trade liberalization and of globalization and their catching up with regional integration long established within the US and across European countries. Freight needs to be moved and exported. Ports are a key element in that strategy. In Latin America, this concern implies that railways also need to be scaled up because in many countries declining reliability and overall quality was such that except for captive shipments, the rail sector had been losing a large share of its potential market to the trucking industry. In Brazil for instance, the odds of relying on rail rather than trucks were lower, the longer the delivery distance. In general, it is becoming increasingly clear to governments that both efficient logistics and the opportunity for multimodal arrangements are essential to competitiveness. The most perceivable outcome of the need to reduce logistic costs is that the private sector will be responsible for large shares of transport services. It is not too risky to predict that this trend is likely to continue as the demand for transport services continues to grow much faster than the government's ability to raise the resources to finance it. 
Finally, Table 2 shows that, just like in developed countries, congestion accessing large cities and between large cities is increasingly common throughout the developing world ${ }^{7}$. This is particularly well recognized in Latin America and Asia were large projects are designed to promote suburban trains and high-speed intercity trains.

7. Highways dominated private activity in toll roads, accounting for $94 \%$ of the investment in $1990-2001$. Most of the toll road projects connected major metropolitan areas, where large traffic flows supported the projects' financial viability. 


\section{FORMS OF PRIVATE SECTOR PARTICIPATION IN TRANSPORT}

While there are many ways of classifying PPP contractual arrangements, most international databases keeping track of these contracts tend to classify them in four main categories:

Divestitures or asset sale contracts transfer ownership of the business to the private sector and all risks are hence "privatized"; it can take many forms - public offerings of shares, or private trade sales of assets themselves;

Greenfield Projects contracts are for specific projects such as a new toll road or port or airport terminal. They cover brand new investment projects which are commissioned to the private sector and Build-Operate and Transfer or Own (BOT or BOO) are among the most common contractual forms. The associated commercial risks tend to be the responsibility of the private constructor while other risks such as exchange or political risks can be shared to varying degrees with the public sector through various types of legal instruments such as guarantees or explicit subsidies. The allocation of these risks in a ring-faced part of a sector is one of the major contribution of project finance techniques that have contributed to the development of this form of contract;

Service contracts for Operation and Maintenance with some investment obligations are essentially contracts to allow a private operator to manage (i.e. operate and maintain) the service but do not include investment obligations. These contracts are typically of short to medium duration (2-5 years) and generally the government continues to take on all risks involved in the project except for the management risks;

Concessions/licences/franchises are usually long term contracts of 10-30 years, which pass on the responsibility for O\&M to a private operator and include detailed lists of investment and service obligations. In this case, the government passes on the commercial risks to the private operator. For many governments, it also has the advantage that it does not imply a politically sensitive transfer of ownership of public assets to the private sector; assets are "rented" out.

In developed countries, asset sales (most obvious in Australia and continental Northern Europe) and concessions/franchises (in the U.K., Southern Europe and Canada) have been the main instruments of private participation in transport infrastructure but not the only one. Additional complementary initiatives abound. The best known may be the Private Finance Initiative (PFI) launched by the UK in 1997 to deliver new and modernize infrastructure to public services. The initiative is interesting because it has been adapted in other developed and developing countries for their transport sector.

Although it had a wider sectoral agenda, the UK's PFI was designed to stimulate the introduction of private sector ownership in public services and the transport sector is an integral part of this program $^{8}$. The PFI in transport has so far been used in projects that are capital intensive and have

8. According to H.M. Treasury (2003), up to 1997 the transport sector had suffered from consistent neglect and a highly damaging lack of investment in infrastructure. 
significant ongoing maintenance requirements. With PFI, the public sector defines what is required to meet public needs and remains the client throughout the life of the contract. The public sector also ensures, by contract, delivery of the outputs it sets. The private sector takes on the responsibility for providing a public service, including maintaining and enhancing or constructing the necessary infrastructure.

While significant, the role of the PFI should not be overestimated. It will account for just $11 \%$ of total investment in 2003-04 (approximately 4.5 billion pounds) and from this amount, the transport sector will get 1.3 billion pounds. The largest transport projects financed through the PFI are the modernization of the London Underground and the M6 Toll Road.

Other European countries are also increasingly relying on PFIs for transport projects. Germany is relying on private investment (construction, operation and maintenance) to extend the federal motorways. A new law (April 2002) provides the legal basis for implementing a distance related toll for the use of motorways by heavy vehicles, which will be the finance source for the investment done by the private sector. Ireland also created a PFI and will also rely on it to fund some toll roads.

Australia, after selling assets and privatizing through long term leases (for instance airports) took the lead in setting administrative rules to ensure access to essential facilities, estimating productivity gains and setting benchmarking mechanisms to compare the performance of all operators 9 .

In developing and transition economies, concessions are the most common form of private sector participation in transport. Table 3 illustrates that concession contracts accounted for $56 \%$ of all transport projects between 1990 and 2001. It also shows that while Latin America and East Asia are the most active in promoting concessions, greenfield projects have been quite successful in East Asia over the last eleven years or so. The Middle East has been the least effective (or maybe the least interested) at building a partnership with the private sector in transport, although there was some activity in private ports. South Asia and Africa come next-including the successful bi-national railway concession between Abidjan and Ouagadougou. Part of the problem is that in these regions most types of risks levels, not only political and regulatory, but also commercial, are high. The ability to pay for transport services in many countries of this region is very modest, implying that tariffs for most passenger services, for instance, have to be quite low. This, in turn, implies rather long-run commitments in order to recover investments.

9. Studies specific to airports, ports and railways can be obtained from the Australian Competition and Consumer Commission (www.accc.gov.au) 


\section{Table 3. Types of Private Sector Involvement Across Countries in Transport in Developing and Transition Economies (Number of projects per contract type between 1990 and 2001)}

\begin{tabular}{|l|r|r|r|r|r|r|r|}
\hline & Africa & $\begin{array}{c}\text { East } \\
\text { Asia }\end{array}$ & $\begin{array}{c}\text { Eastern } \\
\text { Europe }\end{array}$ & $\begin{array}{c}\text { Latin } \\
\text { America }\end{array}$ & $\begin{array}{c}\text { Middle } \\
\text { East }\end{array}$ & $\begin{array}{c}\text { South } \\
\text { Asia }\end{array}$ & Total \\
\hline Divestiture & 3 & 29 & 17 & 7 & 0 & 0 & $\mathbf{5 6}$ \\
\hline Greenfield Projects & 11 & 82 & 12 & 60 & 8 & 23 & $\mathbf{1 9 6}$ \\
\hline O\&M Projects & 12 & 7 & 5 & 14 & 3 & 2 & $\mathbf{4 3}$ \\
\hline $\begin{array}{l}\text { Concession } \\
\text { Contracts }\end{array}$ & 11 & 111 & 9 & 229 & 6 & 16 & $\mathbf{3 8 2}$ \\
\hline TOTAL & $\mathbf{3 7}$ & $\mathbf{2 2 9}$ & $\mathbf{4 3}$ & $\mathbf{3 1 0}$ & $\mathbf{1 7}$ & $\mathbf{4 1}$ & $\mathbf{6 7 7}$ \\
\hline
\end{tabular}

Source: World Bank PPI database.

The distribution of contract types across regions reflects differences in politics, history and risks. Latin America has tended to prefer concession contracts over the other forms because it was believed to be the most effective way of shrinking the fiscal cost of the sector while maintaining the ownership of the assets in the public sector. East Asia, on the other hand, has benefited from the willingness of large local regional financing sources to contribute to expansion projects with high potential payoffs. For the poorest regions such as Africa and South Asia, greenfield projects were effective solutions to isolate risks to specific activities for which these risks would be manageable. New port terminals for instance have often been co-financed by shipping companies for instance. The relatively small proportion of O\&M projects reflects the facts that these types of projects are usually too small to be picked up by this type of database but most importantly, the fact that the PPP wave of the 1990s was mainly designed to get the private sector to take on the investment responsibilities. O\&M contracts come short on that ground and were hence less attractive at the time.

The evolution of contract types does however give a sense that there may be a shift in this view of the world. Indeed, since the Asia crisis, but in particular since the Argentinean crisis, very few new concession contracts have been signed while the number of greenfield contracts have tripled (from 67 to 196) between 1997 and 2001 - the few concession contracts that were eventually signed had been in the pipeline since well before the crisis. The ongoing dialogue with the major sponsors of these contracts is quite clear: they are no longer willing to take on as much risk as in the 1990s.

This increased risk aversion is quite clearly revealed already in the evolution of the financial structure of listed private projects. According to Correia et al. (2004), the leverage rate has been increasingly significantly since 1998 for all infrastructure projects in developing countries but in particular in transport. The debt to equity ratio for most transport projects, based on market value of the assets, is now around $60 \%$, an increase of about $50 \%$ over the mid-1990s values. The cost of capital has also been increasing quite significantly. Estache and Pinglo (2004) show that, based on a book valuation of the financing structure (which has tended to be much more optimistic in recent years with the depressed markets), the cost of capital in rail and ports is around $12-13 \%$ and the cost of equity around $15-16 \%$ on average. Note that for the lowest income countries the cost of equity is significantly higher and reaches close to $20 \%$, at a time when interest rates are at some of the lowest historical levels.

At these costs of capital levels, the willingness to sign concession contracts is bound to decrease and it would seem rational to expect that the demand for contracts requiring no investment 
commitments or only investment commitments paced with the ability of the operator to generate cash is going to surge. At best, even in regions in which concessions tended to dominate, the need to better manage risk is likely to increase the relatively share of greenfield projects. This is already the case for Latin America for instance. Overall, the main beneficiaries are going to be developed countries. With an excess supply of cash on the international financial markets, the willingness of large construction firms to move back to the European market as the liberalization speeds up and proceeds well is already quite obvious for anyone working on project finance.

The evolution of the financing structure, of the cost of capital, and of the forms of contracts is not the only source of evidence to assess the evolution of PPP in the sector. A study conducted by Guasch (2004) of about 1000 concessions contracts signed during the 1990s in Latin America suggests that problems have been in the making for a while now. Defining renegotiation as an event in which a concession contract undergoes a significant amendment in any of the following areas: tariffs, investment plans and levels, exclusivity rights, guarantees, lump-sum payments or annual fees, coverage targets, service standards and concession periods, Guasch finds that transport concessions renegotiation are almost a norm rather than an exception. Indeed, Table 4 shows that $55 \%$ of all transport concessions implemented between 1985 and 2000 in the Latin American and the Caribbean region were renegotiated ${ }^{10}$. This percentage implies that more than one out of every two transport concession contracts has been renegotiated. ${ }^{11}$ It took as little as 3.1 years before the average transport contact underwent a renegotiation.

Table 4. Level and speed of concession renegotiation requests in Latin America

\begin{tabular}{|l|c|c|}
\hline & $\begin{array}{c}\text { All infrastructure } \\
\text { sectors }\end{array}$ & Transportation \\
\hline Percentage of renegotiated contracts & 30 & 54.7 \\
\hline Average time to renegotiate since award (years) & 2.2 & 3.1 \\
\hline
\end{tabular}

Source: Guasch (2004).

As pointed out by Guasch, not all renegotiations were bad. A renegotiation can indeed be a welfare-enhancing instrument when used to address the inherently incomplete nature of concession contracts. Although some renegotiations were desirable, the high percentage of renegotiated contracts indicates the design, implementation and enforcement of concessions contracts will require a careful fine tuning. The main problems identified by Guasch (2004) include the incompleteness of the contracts, the lack of competitive bidding processes with clear and transparent award processes and the absence of an independent an technically well-endowed regulator. It is interesting to note that, in the transport sector, in $57 \%$ of the cases the renegotiation was requested by the operator $(v s .61 \%$ for all infrastructure contracts) and that the Government was the sole initiator in $27 \%$ of the cases, the highest rate across sectors. ${ }^{12}$

10. The empirical findings in Guasch (2004) rely on a dataset of more than 1000 concessions granted in the Latin American and the Caribbean region during 1985-2000.

11. In relative terms, the number of contracts renegotiated are much higher than in the electricity sector and the average of all sectors but it is lower than the percentage in water and sanitation, see Guasch (2004).

12. A fifth one not addressed here is the macroeconomic impact of the reforms specific to the transport sector. While there is a growing volume of publications on the positive effects of the sector on growth levels or 


\section{HAS TRANSPORT DE-REGULATION AND RESIDUAL REGULATION BEEN EFFECTIVE?}

There are three main dimensions on which the effectiveness of the reforms can be assessed: (i) efficiency; (ii) fiscal, (iii) the user viewpoint. To our knowledge, there is no encompassing quantitative study of the effects of reform in developed or developing countries along these three dimensions. Only partial evidence tends to be available. This section reviews this partial evidence (or the lack thereof) and provides a rough assessment of the overall effectiveness of the reforms based on that evidence.

\subsection{Efficiency}

While deregulation in the sector allows for significant intermodal competition which should take care of ensuring efficiency gains to be passed on to the users, natural limits to competition continue to be a major issue in the specific context of transport infrastructures such as port facilities and for captive shippers which are main clients of freight railways in many developing countries. A major indicator of the effectiveness of deregulation and of the residual regulation by the public sector should then be the evolution of the efficiency levels of the sector ${ }^{13}$. The correct measure (or least incorrect) measure of efficiency comes from the estimation of a production or cost frontier which give, respectively, a sense of the maximum production possible from an existing stock of inputs and technology and a sense of the minimum cost possible with the same characteristics ${ }^{14}$. The potential efficiency gains for any operator can then be assessed from the position (and its change in time) of each operator relative to the frontier. ${ }^{15}$ The use of efficiency measurements generated from production frontiers is a suitable instrument not only to assess the effectiveness of reforms but also to foster ex post competition in transport markets. Indeed, it could drive the implementation of yardstick competition schemes aimed at giving stronger incentives to the poorest performers to improve their efficiency.

For developing countries, these efficiency gains should be expected to be particularly important since the initial conditions had been known to deteriorate so dramatically as a result of long lasting fiscal crisis that they facilitate the political support for the reforms of the 1990s. Governments have a variety of objectives when they decide to privatize transport services but the two most important are the need to reduce their fiscal burden and to bring new investment to these services. The quantity and quality of transport services were expected to increase as a result of privatization, primarily as a result of new investments (greenfield projects or maintenance and rehabilitation of existing infrastructure), but also because the private sector was expected to bring in significant new expertise and fewer political constraints that should contribute to improve productive efficiency. From a very pragmatic

growth convergence, there is hardly any study on the marginal effects of transport reforms on these variables. A recent approximation comes from the ex-post evaluations of social rates of return done of World Bank projects focusing on policy reforms in the sectors. These rates of return turn around 35-40\% (see Estache (2004).

13. For a useful and early overview of the US experience, see Winston (1993).

14. Most transport ministries or regulatory agencies tend to focus on partial performance indicators relating 1 input to 1 or more outputs (labor or capital productivity). These are unfortunately often misleading and quite useless for quantitative regulatory decisions.

15. For more details, see Coelli et al. (2003). 
viewpoint, the potential or realized efficiency gains are a good approximation of the extent to which prices could drop in the sector without threatening its financial viability. For passenger services, where tariff continue to be controlled in many countries of the world, they can be used to assess the maximum subsidy the government should be willing to pay.

For developed countries, the decision to deregulate and restructure may have been less of a pragmatic solution to pressing problems and more of an ideological choice supported by the majority of the population through elections. They are nonetheless expected to be important as well, in particular in countries where long traditions of political interference with the management of the sector, including input and output prices, tended to distort investment and production decisions.

Despite its importance for the monitoring of the effectiveness of reforms in their sectors, few regulators in developing as well as in developed countries (with the notable exception of the UK and Australian regulators) have taken on the challenge. There are however a number of studies to draw to get a sense of the potential efficiency gains and of the impact of reforms.

The recent relevant literature is reviewed in Coelli et al. (2003) and more detailed surveys on ports and railways, including an evaluation of the literature on European case studies are available from Gonzalez and Trujillo (2003). Overall, efficiency has tended to improve on average according to most studies although the difference across operators continues to be sometimes very significant. Most of this literature is however not centered on the impact of a reform on the efficiency levels. It tends to focus instead on comparative assessments which do not account as well as expected for differences in institutions, ownership, regulatory regimes or overall political and economic conditions. One of the few exceptions is a recent paper (Friebel et.al., 2003) that estimates the effects on efficiency that the European Commission's Directive ${ }^{16}$ imposed on the railways industry. Using a World Bank's database $^{17}$, this paper argues that reforms -- separation of infrastructure and regulation, third party access and independent regulation -- increased efficiency. However, a striking result is that multiple reforms introduced simultaneously have neutral effects but sequential reforms improve efficiency. For developing countries, the estimation of efficiency and production frontiers is seriously limited by data restrictions. Two exceptions are studies of Latin American reforms. Estache et al. (2002b) shows that the Argentinean and Brazilian railways generated significant efficiency gains. Estache et al. (2002a), estimated average annual efficiency gains in the Mexican port sector, since the reforms were implemented, of around 3\%. This paper highlights the fact that efficiency estimation is feasible and transport regulators have much to win from it. Especially because it allows the promotion of yardstick competition which is crucial to ensure that whatever short term gains are achieved from reform can be sustained and reinforced over the long run.

In sum, the evidence suggests that the efficiency gains have been significant. Their specific source is however less documented than one would have expected.

\subsection{Fiscal}

From a fiscal viewpoint, whenever a reform includes a privatization component, in general, the fiscal impact has been positive, simply as a result of payment from the sale in case of divestiture or

16. EC Directive $91 / 440$

17. Railway Performance Database, The World Bank Transportation, Water and Urban Development Unit. http://www.worldbank.org/transport/rail/rdb.htm. Countries covered are: Austria, Belgium, Denmark, Finland, France, Germany, Italy, Netherlands, Portugal, Spain, Sweden and the United Kingdom. 
from the rental of infrastructures in the case of some concessions. This has been fairly well documented during the 1990s, in particular in the context of the Eastern European reforms. But most of these studies fail to point out a few crucial points. First, the fiscal gains achieved from sales or rental tend be short term gains. A recent study on the Latin American experience which combines debt reductions, sales and rental fee gains shows that while the reforms where indeed effective in maintaining low levels of public investment in the sector, the demand on recurrent expenditures increased through renegotiations [Campos et al. (2003b)]. Most of this increase has come from the demand for subsidies for passenger transport. Indeed, as politicians are reluctant to increase tariffs when costs increase, the only way for private operators to maintain financial viability for a given investment level is to benefit from operating subsidies.

Second, the reduction in total public expenditures is not consistent with the needs and simply implies increased rationing because (i) the private sector has not picked up as large a share of the demand as was expected and hence (ii) the public sector overshot the reduction in its commitment to the sector, not only because the expectations from the private sector were too high but also because the infrastructure in general was one of the public expenditures categories targeted for cuts under fiscal adjustment programs without accounting for the needs and the other macroeconomic implications. According to Calderon, Easterly and Serven (2003) the infrastructure sector (including transport) contributed on average about $50 \%$ of the total fiscal adjustment in the region. This translates into a $1 \%$ lower long-term growth rate for the region....and its own fiscal consequences since lower growth means lower tax revenue.

In sum, the short term fiscal gains have generally been positive but the jury is still out on the long term gains. The evidence indicates that fiscal losses are likely to emerge from the mismanagement of the reform from: (1) a return of operational subsidies; (2) the negative fiscal effects associated with lower growth due to overshooting the reduction in public sector investment in the sector.

\subsection{The user viewpoint}

From the viewpoint of the users, two dimensions need to be considered: price and quality ${ }^{18}$. To address these dimensions, it is useful to distinguish between passenger and freight transport because the concerns are to some extent different.

Starting with passenger transport, the main infrastructure issue emerging from the 1990s may be the financing of intercity and suburban railways where private operators seem to have problems having some degree of financial viability without government support in many lines. Indeed, the control of fares is a regular theme in the media around the world and in the poorest countries a major source of conflict between user representatives, operators and the government. Similarly, in many countries, conflicts have tended to emerge from the closure of unprofitable rural lines leaving some users at least worse off and partly offsetting the fiscal savings derived from reduced service obligations and the gains from other quality improvements (reliability, security, ...) that have resulted from many of the reforms.

Urban transport is less of a problem because it is largely competitive (buses, train, taxis, and similar services all compete for the same passengers in many countries). With the exception of subways where financing is also needed, there is little the public sector needs to do except maybe to regulate quality, ensure that competition takes care of prices and facilitate inter-modal integration. The

18. The importance of quality in the context of transport markets is emphasized by Gomez-Ibanez (2003) in his study of the experience of Sri Lanka. 
main issue may indeed be the need to better manage traffic to address safety and environmental concerns. This is largely being done, slowly but surely, as the concern for pollution has become a worldwide policy item and as, at least in the developing world, the concern with the lack of safety associated with unmanaged competition resulting from excessive liberalizations is now leading governments to consider hybrid solutions.

From the viewpoint of freight transport, the story emerging from the 1990s reforms is somewhat more complex. Most infrastructure privatizations have followed a price cap type of regulatory regime, at least in developing countries. Because these caps have seldom been binding and the competition with the trucking industry has been quite strong, it is unlikely that the average users may have been penalized by the reform. The main residual concern may come from captive shippers (this is discussed later in the paper). As for quality, there is mixed evidence. Visible quality has generally improved (punctuality, safety, ...). Less visible (environment) quality has improved but not as much as expected. Highly visible accidents in the UK have provided highly mediatized (but hardly scientific) evidence of the problem and similar stories are emerging in developing countries. A recent study of the use of under-investment in safety by Brazilian railways operators confirms this [Estache et al. (2004c)].

Overall, the bottom line may be provided by a perception index collected by the World Competitiveness Report. This index gives a sense of what commercial users of transport services feel about the overall quality of infrastructure services. Figure 1 reports the data for each sector and a grouping of countries which allows a double comparison. First, transport is clearly the worst rated of all sectors. Second, this is true across country groups. This suggests that the reforms in the transport sector have in general not been able to generate the level of satisfaction observed for other sectors. 
Figure 1. Commercial perception of transport quality as compared to other infrastructures (per country groups)

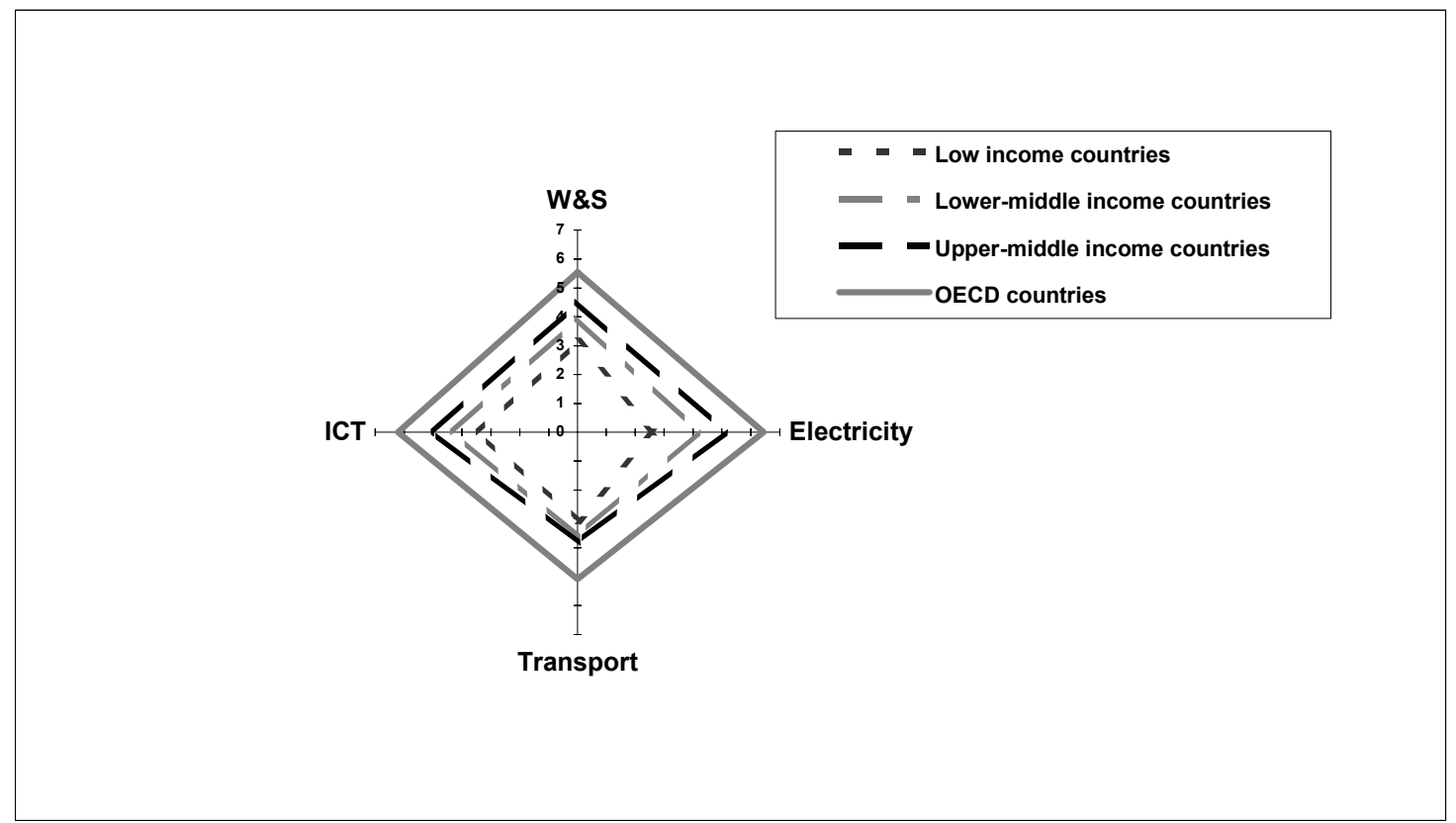

Note: Index based on quality perception: 1=underdeveloped; $7=$ as developed as the world's best.

\subsection{Summing up}

The main message that flows from this very brief overview is a relatively simple one. Deregulation and restructuring did in general improve efficiency, it did improve prices on average, except maybe for captive shippers but it came at a fiscal cost and possibly at a long term quality cost - which may include the lack of a multimodal vision in the design of the sector specific reforms. This fiscal cost is a problem that should have been addressed from the start of the process and which was probably not because most of the fiscal objectives of the reforms were set by teams insufficiently familiar or concerned with the specifics of the sector. The quality and related captive issues are evidence that the residual regulatory role may not have been addressed sufficiently seriously yet.

\section{TOWARD A RE-REGULATION OF THE SECTOR?}

While it is clear that competition should be the dominating policy aimed at in this sector, there is enough evidence to point out to the need for an improvement in the residual regulation to be provided by the public sector in many countries. Based on an informal (and largely personal) observation of the main issues emerging from the 1990s experience, this paper focuses on: 
- Prices: including average prices and tariff structures for monopolies;

- Quality visible (timetables, safety...) and less visible (environment...);

- Access rules for captive shippers and interconnected networks;

- Rebundling of a sector and hence decrease in intrasectoral competition;

- Additional stimulus through yardstick competition;

- The stimulus to multimodalism;

- Local vs. global competition issues.

\subsection{Price regulation}

There are two main types of pricing issues emerging for regulators in the context of the residual regulation of transport infrastructures. The first is the need to recognize that PPP changes the pricing rules in a dramatic way. Indeed, for private investors to consider partnering with the public sector in a sector regulated under price caps or some type of incentive based regulatory regime, the business needs to generate a return at least as high as the cost of capital they are facing. The estimation of the cost of capital is usually done at the time the project finance of the reform is being worked by the privatization team and should be revised on a regular basis by the sector regulator. This is however only done by the best regulators in the world (generally, the Australian and the British) in preparation for scheduled tariff revisions. The only (to our knowledge) transport regulator who has so far gone through this kind of process in the developing countries is the Mexican port regulator. This is quite unfortunate because investors in developing countries are much more sensitive to changes in risk levels, including political and foreign exchange risks and hence expect their tariff to reflect these changes as systematically as possible. Getting regulators to get organized to be able to estimate average tariffs in a way that gives an incentive to operators to commit for the long run is one of the major adjustments needed to the PPP model implemented during the 1990s. Regulation matters and hence regulatory institutions do too and yet the development of the regulatory capacity of the sector continues to lag the development of the equivalent capacity in other public services.

The second pricing issue that has tended to be underestimated has to do with the tariff structure. Indeed, one of the often underestimated dimensions of the interaction between restructuring and fiscal concerns with incidence on prices is the existence of cross subsidies that can be built in the restructuring design. In the airport sector, for instance, it is usually the case that a few airports concentrate most of the traffic, domestic and international, while other airports have volumes of operation that make them financially unsustainable. Under the operation of a public firm, implicit cross subsidies are the norm to keep airports considered necessary or strategic open. Reformers may opt to sell or concession all airports in a package, instead of concession each of them separately and design an explicit subsidy scheme (in 1998, Argentina concessioned 32 airports to only one private consortium). By keeping the implicit cross-subsidies in place, the Government does not need to make explicit subsidies to private operators, which may help implement the reforms, but may lose the possibility of increasing competition between markets. Moreover, by not tracking the level of crosssubsidies explicitly and transparently, the regulators may leave an extraordinary rent to the monopolistic operator of the sector.

Overall, this means that serious regulatory accounting guidelines are needed as well as consultation processes to discuss and implement asset valuations, assessments of potential efficiency gains and economic and financial models to be used by regulators in their transparent decision making. 


\subsection{Quality regulation}

In designing and developing privatization packages for transport services it is essential to improve the accounting for quality alongside the traditional quantity and price aspects. Quality includes service level dimensions, such as journey time, service frequency, or reliability, as well as non-service level dimensions, such as safety and environment.

The rationale to consider quality as an important dimension in the redesign of regulation rests on the evidence on its "adjustment lever" nature. Private concessionaires may take advantage and reduce the quality of the service provided because they may find it commercially convenient to save on costs or because informational advantages and the difficulty of monitoring service levels make it easy not to comply with pre-agreed quality-related standards. Lowering quality is often the way private operators "adjust" to increased competition from other operators, or the way an operator working within a monopolistic framework (e.g. under a licence agreement as the sole operator in a given route) may exploit monopoly power and adjust service quality according to demand responsiveness. Thus, quality matters both in competitive and monopolistic structures where transport services are being privately provided.

The presence of private operators in partnership with the public sector will require a re-allocation of responsibilities regarding safety and environment. Many safety and environment standards tend to be set by national legislation and frequently fall under the responsibility of national bodies, such as Health and Safety Executive, or a Ministry of Environment, or Environment Agency. A particularly important aspect of setting safety standards include provisions for third party liability insurance, in particular, the need to assess the amount of cover necessary, the extent in which operators are able to insure at reasonable terms in the insurance market, and the amount of self-insurance allowed. Dispute resolution in case of a serious accident occurrence among the parties involved regarding liability and cost recovery allocation should also be carefully assessed. Generally, environment standards will be set and monitored by environmental authorities based on standards set nationally or supranational. Nevertheless, the concession/franchise awarding authority may use environmental quality indicators in the valuation of bids; and the regulator may be delegated to monitor compliance with environment standards on behalf of the environment agency. In those circumstances it will be a condition of the operator's license to show commitment by specifying a plan and the management means to achieve it.

\subsection{Access regulation and competition policy}

In the provision of transport services, some facilities are necessary inputs in the production process of transport services. That is the case of airports in air transport, loading docks in maritime services and rail tracks in railway services. When antitrust authorities include only one facility in a

relevant geographic market ${ }^{19}$, this facility is considered essential. In practical terms, an essential facility implies that it is not economically reasonable to duplicate the facility. If only one facility must be used by all service providers, the establishment of rules to determine how, when and at what prices access is allowed is the key to guaranteeing effective competition in the market.

Unless access pricing rules are defined before the business is passed on to private operators, it is clear that rents are being created that are harmful to users. This has long been an issue in the US, it is an issue in the UK and it has proven to be an issue in most developing countries where the need to

19. A relevant geographic market is the minimum area where a hypothetical monopolist can profitably increase prices. In other words, is the minimum area where there is no effective competition because consumers can not demand services from other suppliers. 
transfer the business to private operators is often so pressing that there is little time to work out the demanding details of access pricing.

In general, when reformers identify an essential facility, they create a regulator that sets access tariffs and other conditions designed to avoid undue discrimination. The relevant question is whether the regulator is strong enough to deter the monopolist to abuse its dominant position. Of particular relevance are the cases where the monopolist can compete with the providers of services in those segments that are deregulated. In the case of railways, can the operator of the rail tracks own and compete with other companies that own trains and operate on those tracks? can an airport operator own an airline that use that airport as a hub and compete in a deregulated market?

Without access price regulation, it is clear that the operator of the essential facility can extract all the rent from the operators that use the facility. However, when there is access price regulation but the concession contract or the privatization law says nothing about the possibility of vertical integration, the operator of the essential facility has strong incentives to control an operator downstream and implement a rising rivals' cost strategy to exclude all competitors and become a monopolist both upstream and downstream. Even when prices are regulated, there are a wide variety of conducts that can be implemented by the operator of the essential facility whose purpose is to reduce competitors' quality of service which is equivalent to increase their costs.

When restructuring a transport sector, what can governments do to establish an adequate access regime?. One extreme solution is a strict vertical separation between control of infrastructure and users of the infrastructure. The disadvantage of this alternative is the likely loss of economies of scope and adequate information to plan infrastructure investments ${ }^{20}$. If governments decide not to prohibit vertical integration, to avoid future attempts to vertically integrate through access discrimination it should implement an adequate open access regime, complemented with rules of accounting separation and it should set up a regulator with enough resources to be a credible watchdog of competition. Some countries, New Zealand being the best example, prefer not to impose any restriction on the market structure and rely on the competition agency to avoid the application of any anticompetitive conduct.

The airport sector provides an example of the variety of approaches adopted with respect to the degree of vertical integration. Australia and Chile have explicit rules against vertical integration: Australia limits an airport operator's ownership stake in airline to 5 percent and in Chile, the bidding guidelines for airport concessions specify that the infrastructure concessionaire can not have decisive influence over the administration or management of companies offering air transport services. Although the private sector does not have a significant role in the airport sector in Continental Europe, the European Commission also recognized the potential problems of vertical integration in its analysis of the propose merger between Air France and Sabena in $1992^{21}$.

International experience, including the recent ruling by the Argentine antitrust agency that rejected a merger attempt by the operator of 32 airports to buy an airline, suggests that developing countries restructuring transport markets should include an explicit prohibition on vertical integration (impose vertical separation) between the owner or operator of the essential facility and its users. This regulatory approach has several major advantages: it keeps the costs of monitoring and information gathering low, eliminates the incentives to transfer market power to the competitive segment, reduces

20. For instance, in the case of airports, airlines have ample information on trends in air traffic demand that is needed to plan infrastructure investments. But with an adequate information regime embedded in the regulatory framework these benefits can be obtained without vertical integration.

21. European Commission. Air Fance-Sabena IV/M 157. 
conflicts between the regulatory and competition agency and provides certainty to transport service providers in the competitive segment.

\subsection{Rebundling}

In practice, restructuring generally implies some degree of unbundling of the activities performed in each sub-sector and it consists in an actual disintegration of the monopoly into various business units. The restructuring can be horizontal, creating companies that deliver very similar activities. This is common in railways (many companies providing freight or passenger services), ports (companies operating different terminals within one port or one company operating each of many ports in a given region) and airports (one airport per private operator in a given country). Unbundling can also be vertical and determines the extent to which a single firm can participate in different vertically related stages of production. For instance, in the airport sector, vertical unbundling implies that the airport operator can not hold a controlling stake in an airline that operates from that airport.

Despite the initial desire to cast the market structure to increase competition in the market, operators seem to be increasingly tempted to subsequently try to concentrate horizontally or vertically. An example of unbundling followed by a process of rebundling is given by the port sector in Argentina. ${ }^{22}$ In the early 1990s Argentina restructured and privatized its port system. As part of this process, Puerto Nuevo's six terminals (the largest port in Argentina) were offered to the private sector under long-term concessions. The government showed a concern for competition throughout the concession process, imposing conditions that would result in a market structure capable of sustaining competition: bidders were allowed to bid for more than one terminal, but they had to express a preference and could be awarded only one. The conditions imposed by the government implied a prohibition on horizontal mergers between terminals. However, reformers were not concerned about the vertical structure of the market. Thus, $\mathrm{P} \& \mathrm{O}$, a multinational firm that operates both terminals and a maritime shipping company, was awarded two terminals and in 2001 the Argentine Antitrust Commission approved the acquisition of a terminal by Maersk Sea Land.

After only six years of the start of the concession, in 2000, probably because of excess capacity, three terminals proposed to merge. Allowing this merger would imply a change to Puerto Nuevo's regulatory framework which explicitly prohibited mergers between terminals. When should governments allow a rebundling process to take place? Is it advisable to allow mergers between port terminals? Providing an answer to these questions involves debating about the convenience to commit to the text of a regulatory framework or to choose a flexible scheme to adapt to a changing economic environment, in particular the recognition that the cost of capital has increased significantly and that rebundling may be a rational strategy to maintain it at a competitive level. In Argentina, the government opted to change the regulatory framework and allow, subject to the ruling of the antitrust agency, horizontal mergers in the port sector. In the port sector, as in any other transport market, antitrust agencies must do a cost-benefit analysis to assess the effect of mergers on competition and consumer welfare.

More generally, in transport markets, firms will cite efficiency gains as the main reasons to merge, achieved through: potential for economies of scale, the possibility of rationalizing resources, and the presence of actual or potential intra and intermodal competition. On the other hand, antitrust agencies must carefully consider the potential harmful effects of mergers on competition. These are the consequence of barriers to entry, strategic (an example applied to the port sector is signing long

22. See Serebrisky and Trujillo (2003) for more details. 
term contracts with all shipping companies to prevent the construction of a new terminal or nearby port) or legal.

\subsection{Additional stimulus through yardstick competition}

The deregulation of the sector has often resulted in the creation of local or regional monopolies in airports, rail and ports. This overall reform process in the sector is generating a significant increase in the number of combinations of public and private operators involved in these businesses. This new market structure is providing a unique opportunity to introduce yardstick competition in transport markets in such a way that it could become an effective regulatory tool in this sector as it has become in the utilities sector. Indeed the formal introduction of interregional competition in these sectors could be designed to promote efficient management of services otherwise operating under local monopolies. Yardstick competition allows the performance in the various operators of a given sector to be compared over time, continuing the competitive pressure. In fact, while no country has yet experienced formally with this tool in the transport sector (with the exception of the Mexican port sector), many new regulators recognize its importance to ensure the sustainability and to improve the initial gains achieved through the restructuring and privatization process

This will of course require a much stronger commitment to regulatory processes and procedures that allow the generation of consistent international databases as has been the case in water or energy for instance.

\subsection{The stimulus to multimodalism}

One of the big failures of the design of the 1990s reform in developing countries and a major gap with respect to achievements in developed countries is that reforms followed a piecemeal approach without an integrated vision for the sector. Every subsector had its PPP team and seldom talked to each other while ignoring the possibility of favoring intermodal integration. Yet, high logistics efficiency tends to require competitive incentives for service providers to continuously innovate and to seek out lower cost combinations of transport services in a coordinated way to minimize confusion and increase the predictability of the environment in which transport operators make investment decisions.

For many developing countries still lagging, it might be preferable to simply adopt the relevant standard international statute/s to ensure international compatibility. To do so, governments need to clarify the public service obligations of core transport service providers-such as port, rail, and intracoastal and water barge operators-including the obligation to provide open access to their service networks to third-party users, such as commercialization agents (e.g., freight forwarders, multimodal transportation operators) who are qualified to integrate the core transport modes into door-to-door service packages under a single bill of lading. Several types of rules and standards promoting "connectivity" among stand-alone services and "interchangeability" of intermodal equipment among carriers will be required to ensure that an integrated network will work effectively and to give multimodal service providers a much better basis for understanding how they can develop markets for multimodal services. 


\subsection{Local $v$ s. global competition issues}

In spite of all the efforts made by reforming governments, it seems that competition for the market is not working that well in most developing countries at least. Typically the number of serious bidders for a concession or a greenfield project in transport infrastructure is not much higher than 2-3 - there are of course examples with more players but a large number of players is not the norm in infrastructure concessions. Technically, this is competition of course but it is not impressively strong competition. The fact is that if it were not for the foreign bidders, it would often be the case that the sector would remain in the control of a very limited number of local players. Most typically these players are local construction companies which have historically been winning all the procurement contracts offered by the public monopolies to implement their investment programs. The opening of the sector is at least ensuring that even if foreign specialized operators are not interested, foreign construction companies will be able to compete with the local construction firms in putting together bids for these contracts.

The simple fact is that the transport sector is a highly concentrated sector internationally as well. This issue has been raised for quite a while now in maritime transport where shipping companies are increasingly integrating vertically to take over the container terminal business. There is indeed casual evidence of increases in dedicated terminals in which one shipping company monopolizes at least part of the port infrastructure. This is the case in Antwerp wit MSC and Rotterdam with Maersk but also in Santo Domingo and in Buenos Aires. Sometimes there are good reasons to reduce the number of terminals, including the increased cost of capital in emerging economies which make mergers an effective risk management instrument as mentioned earlier. But with the ongoing wave of mergers or alliances between maritime companies there is a reason to wonder about the risk of effective inter-port or inter-terminal competition that results from the reduction in the number of suppliers of maritime services. Similar issues arise in the airport management business where the same 5-10 usual actors seem to be present at all bids ${ }^{23}$.

The least recognized indicator of concentration at the global level may be in the construction sector which is at the core of all new infrastructure projects. Working with statistics published by Public Works Financing, the construction deals on all of infrastructure (transport + utilities) are highly concentrated in very few hands. Indeed, 6 companies share $50 \%$ of the market and 16 companies share $90 \%$ of the market. Spanish companies (Dragados, Ferrovial, Abertis, OHL, FCC, Acciona and Sacyr), accounted for $52 \%$ of all new concessions and PPP projects over US\$50 million under construction and signed between 1985 and 2003. British companies (John Laing, AMEC, Balfour Beatty and Alfred McALpine) accounted for $14 \%$ as well as French Companies (Vinci-Cofiroute, EGIS, Bouygues, Alstom) while Australia accounted for 9\% (Macquarie). In sum, 10 companies share about $90 \%$ of the market! The concentration is quite impressive since many of these companies have a certain degree of regional specialization.

The point is that effective ex-ante competition tends to be modest even in some of the best organized auctions and that the opening of trade in services is not changing much the picture. But there is more to be squeezed out of the experience. In particular, it is interesting to look into the specific nature of the bidding companies. In many cases, the bids are made by consortia combining local and foreign companies. There are of course gains in terms of transfer of know how and reductions of overall risks associated with these strategies. But the gains may some time have to be weighted against the cost induced by lesser competition.

23. For more details and examples, see Estache (2001). 


\section{CONCLUSIONS}

Three main points emerge from the paper. The first is that deregulation has generally had different effects in developed and developing economies. Project sizes are larger for developed countries and their relative contribution to the needs is larger as well (in most developed countries installed capacity is usually much larger already and marginal projects have tended to have a much larger marginal impact). The fiscal payoffs have generally been good in the short run but less predictable in the long run, certainly in the case of developing countries, often as a result of contract renegotiations. As for the users, the payoff from reform is somewhat different for passenger and freight transport. The passengers have seen improvements in the quality of services, have more options to chose from and often face relatively low prices, but often because the government has kept a tight control - with important fiscal consequences. The freight shippers are also better off overall as a result of deregulation and restructuring. The potential for improvement is however still strong. Few countries have reached their potential in terms of modal integration. Moreover, safety in some cases continues to be an issue and the increased concern for security resulting from September 11 is unlikely to smooth things out.

The second is that the odds of the private sector playing a strong role in the transport infrastructure of all countries of the world are low. The concentration rate of projects is significant. OECD and a hand-full of developing countries is where the private sector has gone and will continue to go, at least for a while and until developing countries manage to generate politically viable projects (from the user viewpoint) with returns sufficiently high to match the high cost of capital associated with the perception of high risk associated with many developing countries. Many of the "not chosen countries" have made strategic mistakes cutting the public sector commitments in the hope that the private sector would do it and are now forced to play catch-up for supply to meet demand.

The third, and maybe the most important point, is that the policy agenda associated with the follow-up to the strong commitment to deregulation and increased private sector participation is far from being small. The issues reviewed in section 5 (prices, quality, access, rebundling, multimodalism) are often complex to address. The corrections needed to the reform path require a strong political commitment at the national as well as at the international level. This commitment is needed because addressing these issues implies strong redistribution of rents politicians are seldom willing to implement. Ultimately, the sustainability of the reforms and the ability of the public sector to use money more effectively in leveraging private money (including guarantees and subsidies) will depend significantly on this political commitment to effective regulatory and competition policy. History suggests that fine-tunings are often more difficult to implement than large reforms. If transport ministers are to endorse this emerging policy agenda, a new hybrid model of PPP will emerge with a significantly larger positive impact for users, operators and current as well as future taxpayers. 


\section{BIBLIOGRAPHY}

Alexander, I., A. Estache and A. Oliveri (2000), “A Few Things Transport Regulators Need to Know About Risks", Utilities Policy Vol. 9 No 1 pp 1-13.

Benitez, D. and A. Estache (2004), "How concentrated is the control of the infrastructure subsectors in the world?", mimeo, The World Bank, Infrastructure Vice Presidency.

Calderon, C., W. Easterly and L. Serven (2003), "Latin America's Infrastructure in the era of Macroeconomic Crises", in Easterly, W. and L. Serven (2003), ed. The Limits to Stabilization -- Infrastructure, Public Deficits and Growth in Latin America, Stanford University Press, pp 21-94.

Campos, J., A. Estache and L. Trujillo (2003a) "Processes and accounting matter for regulators: Learning from Argentina's railways privatization", Journal of Network Industries.

Campos, J. A. Estache, N. Martin and L. Trujillo (2003b), "Macroeconomic Effects of Private Sector Participation in Infrastructure", in Easterly, W. and L. Serven (2003), ed. The Limits to Stabilization - Infrastructure, Public Deficits and Growth in Latin America, Stanford University Press, pp. 139-170.

Correia, L., A. Estache and S. Jarvela (2004), "Evolution of the financial structure of infrastructure projects in developing countries" mimeo, The World Bank, Infrastructure Vice Presidency.

Coelli, T., Estache, A., Perelman, S., and Trujillo, L. (2003). "A Primer on Efficiency Measurement for Utilities and Transport Regulators". The World Bank Institute Development Studies., Washington, D.C.

DFID (2002), "Making connections: infrastructure for poverty reduction", mimeo, available at http://62.189.42.51/DFIDstage/FOI/dc/7mar02_making_connections.pdf

Drewry Shipping Consultants (2002), Global Container Terminals- Profits, Performance and Prospects, London.

Estache, A. and M.E. Pinglo (2004a), "What is the cost of capital for infrastructure projects in developing countries?”, mimeo, The World Bank, Infrastructure Vice Presidency

Estache, A. (2004b), "Do Ex-post evaluation of the social rate of return on transport Projects match the results from econometric studies?" mimeo, The World Bank, Infrastructure Vice Presidency.

Estache, A., S. Perelman and L. Trujillo (2004c), "Towards Quality Adjusted measure of efficiency gains in freight railways: evidence from Brazil", mimeo, The World Bank, Infrastructure Vice Presidency 
Estache, A., Gonzalez, M., and Trujillo, L. (2002a). "Efficiency Gains from Port Reform and the Potential for Yardstick Competition: Lessons from México", World Development, Vol. 30, No 4, pp 545-560.

Estache, A., Gonzalez, M., and Trujillo, L. (2002b). "What Does Privatization Do for Efficiency? Evidence from Argentina's and Brazil's Railways", World Development, Vol. 30, No 11.

Estache, A. (2001), "Global Competition Issues in Infrastructure Services Trade", The World Bank, mimeo.

Estache, A. and de Rus, G., ed. (2000). "Privatization and Regulation of Transport Infrastructure: Guidelines for Policymakers and Regulators". The World Bank Institute Development Studies, Washington, D.C.

Friebel, G., Ivaldi, M., and Vibes, C. (2003). "Railway (De)Regulation: A European Efficiency Comparison". IDEI Report \#3 on Passenger Rail Transport. Institut d'Economie Industrielle, University of Toulouse.

Gomez-Ibañez (2003), Regulating Infrastructure: Monopoly, Contracts and Discretion, Harvard University Publication, Boston.

Gomez-Ibanez, J.A. and J.R. Meyer (1993). "Going Private: The International Experience with Transport Privatization, The Brookings Institution, Washington, DC.

Gonzalez, M. and L. Trujillo (2003), "Medidas de eficiencia en Ferrocarriles y Puertos: Una revision de la literatura", mimeo, Universidad de Las Palmas de Gran Canaria.

Guasch, J.L. (2004). "Granting and Renegotiating Infrastructure Concessions. Avoiding the Pitfalls". The World Bank Institute Development Studies, Washington, DC.

Kennedy, D. (1997), "Regulating Access of the Railways Network", Utilities Policy, Vol. 6. No 1. pp. 57-65.

Public Work Financing (1995, 1998, 2003), "International Major Projects Survey", Public Works Financing. October.

Serebrisky, T., and Trujillo, L. (2003). "Market Power: Ports. A Case Study of Postprivatization Mergers". Viewpoint 260. The World Bank. Washington, D.C.

Serebrisky, T. (2003). "Market Power: Airports. Vertical Integration between Airports and Airlines". Viewpoint 259. The World Bank. Washington, D.C.

Trujillo, L., E. Quinet and A. Estache (2002), "Dealing with Demand Forecasting Games in Transport Privatization", Transport Policy, Vol. 9, No. 4, October.

Wilson, T. (1999), "The Private Finance Initiative”, Infrastructure Journal, Winter: pp. 35-43.

Winston, C. (1993), "Economic Deregulation: Days of Reckoning for Microeconomists", Journal of Economic Literature, 31: pp. 1263-89. 